\title{
Changes in the population density of the horse-chestnut leafminer, Cameraria ohridella and of its parasitoid community at Hédervár during 7 consecutive years (1998-2004)
}

\author{
Horváth, B. ${ }^{1}$ \& Benedek, P. ${ }^{2}$ \\ 'Ásványráró, Szerszámgépgyáru. 7.,H-9177 (e-mail: eos5@freemail.hu) \\ ${ }^{2}$ University of West Hungary, Faculty of Agricultural and Food Science, Mosonmagyaróvár, Vár 2, H-9200 \\ (e-mail:benedek@mtk.nyme.hu)
}

\begin{abstract}
Summary: Studies available up to now usually report changes in populations of Cameraria ohridella and its parasitoids in a period of 3 years or shorter. Due to the limited duration of investigations, no tendencies of changes could be disclosed and, according to the general idea, the infestation level of the horse-chestnut leafminer and the rates of parasitism do not change significantly. Based on our examinations carried out throughout 7 consecutive years we suggest that the infestation level of $C$. ohridella is generally decreasing and the rate of parasitism is increasing. A possible adaptation of the parasitoids to this new host is showed on the changes of parasitism. In contradiction with earlier studies, authors assume that a partially stable permanent parasitoid community is being developed around the horse-chestnut leafminer. Proportions of adult moths and parasitoids hatched in the same year of sampling or the next year were determined.
\end{abstract}

Key words: adaptation, Cameraria ohridella, horse-chestnut leafminer, parasitism, parasitoid community

\section{Introduction}

The horse chestnut leafminer, Cameraria ohridella was first discovered in Macedonia in 1985 but became a widespread insect pests in Europe during the pas two decades (e.g. Sefrová \& Laštiovka 2001, Śefrová 2003, Heitland et al. 2003). Although numerous publications deal with the biology and the parasitoid community of the moth, all studies follow its population changes during a period no longer than 3 years or shorter and no long-term investigations have been made so far. In the present study we offer a survey of the changes we experienced in the leafminer's population and in its parasitoid community over a period of 7 years.

\section{Material and methods}

Investigations were carried out in Hédervár, North-West Hungary, from 1998 to 2004 . In the course of this time, we used different methods of research as our yearly intentions changed; in this paper we present a summary of the resullts with a view to long-term changes.

\section{Studies in 1998}

On the 3rd and 21st of October 1998 and on the 27th of February 1999 - before the flight period of the wintering generation - we collected fallen horse-chestnut leaves and put them in paper sacks. Each sample consisted of 1100 pieces of leaflets. The sacks were stored under shelter but at a temperature identical to the outdoors. Before the moths and the parasitoids started to hatch in the spring, transparent jars were fastened in the mouths of the sacks to make insects gather in the jars when flying towards light. The jars were emptied every day, the moths counted and the parasitoids collected for determination. All the parasitoids were identified by dr. Csaba Thuróczy, Systematic Parasitoid Laboratory, Köszeg. Since non-chalcidoid individuals (Ichneumonoidea: Ichneumonidae, Braconidae) were very rare and hatched only occasionally, and the specialists needed were not available, solely chalcidoid parasitoids were taken into consideration during the whole investigation period ( 7 years).

\section{Studies in 1999}

On the 8th of October 1999 we collected leaves both from the lower branches $(1,5-2,5 \mathrm{~m})$ and from the top of a tree $(12-13 \mathrm{~m})$. The leaves were put in two distinct paper sacks according to the level they were collected from. The first sack - with leaves from lower canopy - contained 1100 leaflets. The second sack held 1200 leaflets collected from the top. Despite of the slightly greater number of leaflets, this sample was much less in volume. As a year earlier, both 
sacks were stored under shelter but at a temperature identical to the outdoors. Fastening jars in the mouths of the sacks, emptying them on a daily basis, counting insects and sorting out parasitoids for determination were done just like in the previous year.

\section{Studies in 2000}

On the 14th or 20th of October 2000 leaf samples were taken from three levels of the canopy of horse-chestnut trees: one from the lower $(1,5-2,5 \mathrm{~m})$, one from the middle (ca. 5 $\mathrm{m})$ and one from the higher level of the canopy $(12-13 \mathrm{~m})$. Half of the samples from the lower branches were taken on branches exposed to the sunshine and the rest from the shade; the sample from the middle levels contained shaded leaves only since sunlit parts of the canopy were practically out of reach. The leaves from the top were exposed to direct sunlight during the whole day. The samples were put in three distinct paper sacks according to the level they came from. The sacks were stored and the insects were reared just like in the previous year. After hatching had come to an end, the mass of each dry leaf sample was measured with $0.01 \mathrm{~g}$ accuracy on a digital scale.

\section{Studies in 2001}

From June 26 to October 23, 2001, leaf samples were taken fortnightly from several different parts of the horsechestnut tree canopy. Samples from the lower braches were collected on 9 occasions altogether, 60-60 leaves each time. Half of each sample ( 30 leaves) consisted of sun-exposed, the other half ( 30 leaves) of shaded leaves. From the top of the canopy, samples - consisting of 60 sunlit leaves - were taken 9 times during the year. From the middle levels we collected 8 samples, 30 shaded leaves each time. On three occasions (26. 6., 100 pieces; 9. 7., 50 pieces; 1. 8., 100 pieces) we also collected minute leaves from the inner canopy; they were attached to thick boughs and all shaded.

In this year, some of the paper sacks were opened in January 2002 and the samples were searched for hatched insects. After sorting out insects, the sacks were closed again and put back for a second review in the summer.

According to collecting data and leaf type, the samples were put in sacks made of newsprint paper. The sacks were carefully closed and stored in unheated rooms until insect hatching ended. In the summer we opened the sacks and the hatched adult insects - all dead by that time - were counted and the parasitoids were kept for later determination. After sorting out insects, the mass of each dry leaf sample was measured with $0.01 \mathrm{~g}$ accuracy on a digital scale.

\section{Studies in 2002}

Between June 9 and August 14 leaf samples were taken with 2 weeks intervals from the horse-chestnut trees. Three kinds of samples were taken: one from sunlit parts of the lower canopy ( 30 leaves a time), one from shaded parts of the lower canopy ( 30 leaves a time) and one from the sunlit top of the canopy ( 30 leaves a time). From late of August additional samplings came to grief due to early leaf falling. Putting the samples in newspaper sacks and wintering in an unheated room, sorting out adult insects and parasitoid determination were done just like in the previous year.

\section{Studies in 2003}

Between June 7 and September 28 leaf samples were taken with 2 weeks intervals from the horse-chestnut trees. Two kinds of samples were taken: one from the lower branches (sunlit as well as shaded leaves, altogether 30 pieces a time) and one from the top of the canopy (30 sunlit leaves a time). Putting the samples in newspaper sacks and wintering in an unheated room, sorting out adult insects and parasitoid determination were done just like in the previous years.

\section{Studies in 2004}

Between July 3 and October 3 altogether $2 \times 13$ leaf samples were taken from the horse-chestnut trees. We distinguished between two kinds of samples, one from the sunlit parts of the lower canopy ( 15 leaves a time) and one from the shaded parts of the lower canopy ( 15 leaves a time). The samples were put in sacks made of newsprint paper. The sacks were carefully closed and stored in an unheated room up to the end of February 2005. After that date we carried the sacks into a heated room to accelerate the insects development. Sorting out adult insects after swarming and determining parasitoids were done just like in the previous examinations.

\section{Calculating the rate of parasitism}

The rate of parasitism was estimated as below:

$$
R P=100 * p /(m+p) \text {. }
$$

where 'RP' is the rate of parasitism, 'p' is the total number of (chalcidoid) parasitoids and ' $m$ ' is the total number of moth individuals hatched from the sample. Obviously, this calculation does not allow exact conclusions, yet it is sufficient enough to estimate levels of parasitism and compare samples or years.

We also defined each species' contribution to the parasitism, which was calculated according to the formula below:

$$
R P_{s p}=100 * p_{s p} /(m+p) .
$$

where ' $p_{\mathrm{sp}}$ ' is the number of hatched individuals of the parasitoid species under discussion. If we add together 'RP $\mathrm{sp}_{\mathrm{sp}}$ values of each parasitoid species hatched from the sample, the sum total equals the rate of parasitism (RP) for the sample in question:

$$
R P_{s p 1}+R P_{s p 2}+R P_{s p 3}+\ldots+R P_{s p n}=R P,
$$

where ' $n$ ' is the number of parasitoid species hatched from the sample. (Similarly, $\left.p_{s p 1}+p_{s p 2}+p_{s p 3}+\ldots+p_{s p n}=p\right)$ 
Table $I$ Total insect material reared and the rate of parasitism in the seven years study period

\begin{tabular}{|c|c|c|c|c|c|}
\hline Year & $\begin{array}{c}\text { Number of } \\
\text { moths reared }\end{array}$ & $\begin{array}{c}\text { Number of } \\
\text { parasitoids reared }\end{array}$ & $\begin{array}{c}\text { Number of } \\
\text { reared parasitoid species }\end{array}$ & $\begin{array}{c}\text { Rate of } \\
\text { parasitism (\%) }\end{array}$ & $\begin{array}{c}\text { Number of moths hatched } \\
\text { per one compound leaf }\end{array}$ \\
\hline 1998 & 5309 & 530 & 12 & 9.08 & 11.80 \\
\hline 1999 & 3900 & 522 & 9 & 18.94 & 24.13 \\
\hline 2000 & 1502 & 351 & 9 & 28.30 & 2.49 \\
\hline 2001 & 4200 & 1658 & 14 & 12.43 & 3.04 \\
\hline 2002 & 2282 & 324 & 9 & 32.35 & 5.07 \\
\hline 2003 & 1146 & 548 & 13 & 17.17 & 2.25 \\
\hline 2004 & 4323 & 896 & - & -2 & 10.29 \\
\hline Total & 22633 & 4811 & 10.6 & 9.58 & \\
\hline Mean & & - & & & 7.96 \\
\hline
\end{tabular}

\section{Results and discussion}

During the 7-year-investigation period, 22.633 individuals of horse-chestnut leafminer and 4.811 individuals of chalcidoid parasitoids have been reared from the leaf samples altogether (Table I). The rate of parasitism, the specific structure of the parasitoid community, the proportions of the parasitoid species and its contribution to the parasitism, the number of individuals that hatched from the samples was very different among years (Tables $1-3$, Figure 1 ) and in sun-exposed and shaded parts of the canopy (Figures 3-5). None of the moth pupae from autumn samples hatched prior to January, while the parasitoids emerged partly before January and partly later (Table 4).

\section{Rate of parasitism of Cameraria ohridella populations}

Natural enemies usually play an important role in the control of leafminer populations and the rate of parasitism may come near to or exceed 50\% (Grabenweger 2003 citing other authors, Balizs 1997). Obviously, these parasitoids must have had plenty of time to adapt themselves to the host. This was not the case with the horse-chestnut leafminer and its parasitoid community. Many authors reported parasitism rates of $5 \%$ or less (Freise \& Heitland 2004). In these cases parasitism is not a major mortality factor of $C$. ohridella. This is not surprising as $C$. ohridella looks back on a history of only 20 years in Europe. Its parasitoids are exclusively polyphagous and have been long known from other

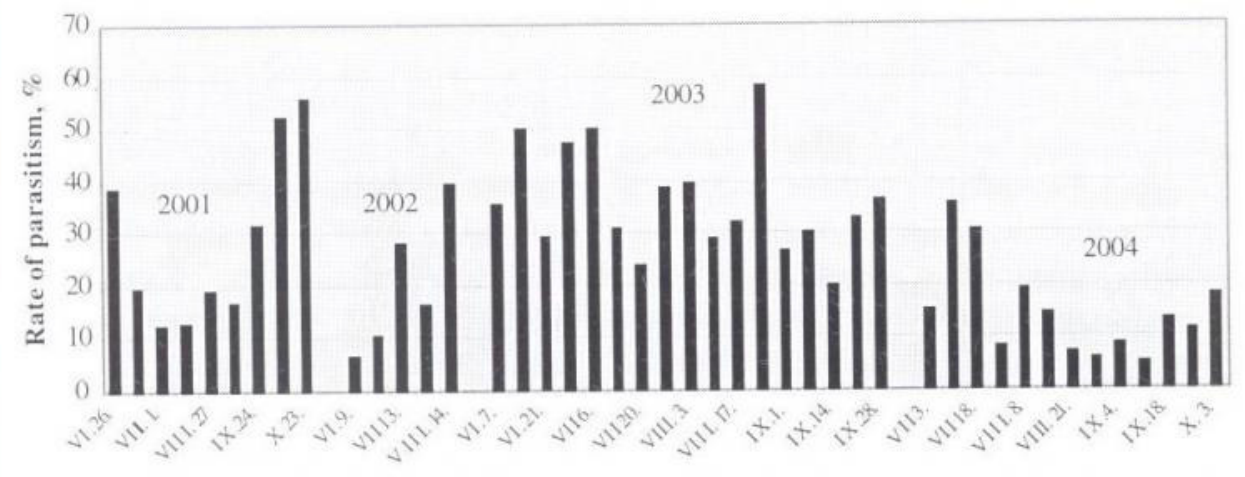

Figure 1. Seasonal dynamics of rate of parasitism on Cameraria ohridella at Hédervár between 2001 and 2004 leafminer hosts (Balázs \& Thuróczy 1999, 2000). These parasitoids had only two decades at most to adapt themselves to the new host - the lack of enough time results in low rates of parasitism and a serious damage on the foliage of the trees. The situation is even worse in Hungary due to the late appearance of the new pest in 1993. In 1994 it was found in Györ (Szabóky \& Vas 1997) that is situated ca. $25 \mathrm{~km}$ off of our survey location, Hédervár. Supposed it was already present on the avenue of horse-chestnut trees in Hedervár in 1994, even then, the parasitoids had only 4 years for adaptation until our investigations begun. This makes the low rate of parasitism found in the first year of our investigation understandable.

However, in certain cases parasitism of $C$. ohridella can reach values as high as $30-40 \%$ or even $81 \%$ (Thuroczy \& Reiderné 1998, Balázs \& Thuróczy 1999, Reider Saly et al. 1999, Lupi 2005). In these cases the very high abundance of parasitoids can exert a visible abating action on the pest population and on leaf damage (Lupi 2005) and the need for a chemical protection is disputable (Balázs \& Thuroczy 1999).

Data in Table $I$ show that the parasitism of $C$. ohridella was growing constantly from 1998 to 2001 and the rate of parasitism changed more than threefold. Of course, our competence in comparing data is limited due to more or less different procedures of examination in certain years. However, each year - unintentionally in the case of fallen leaves and deliberately in other cases - we summarized data of different leaf types and canopy levels what makes results of different years comparable. In 2002 rate of parasitism fell back on a value similar to year 1999 but the next year it was nearly as high again $(32.35 \%)$ as it probably would have been without this recession. The parasitism in 2004 was lower again, roughly the level of the year 2000. Unfortunately, we do not have data from 2005 but based on the results of the previous years we would expect it to be even higher than it was in 2003 .

According to our data from 7 years we suppose that the adaptation of the native parasitoids to the horse-chestnut 
Horváth, B. \& Benedek, P.

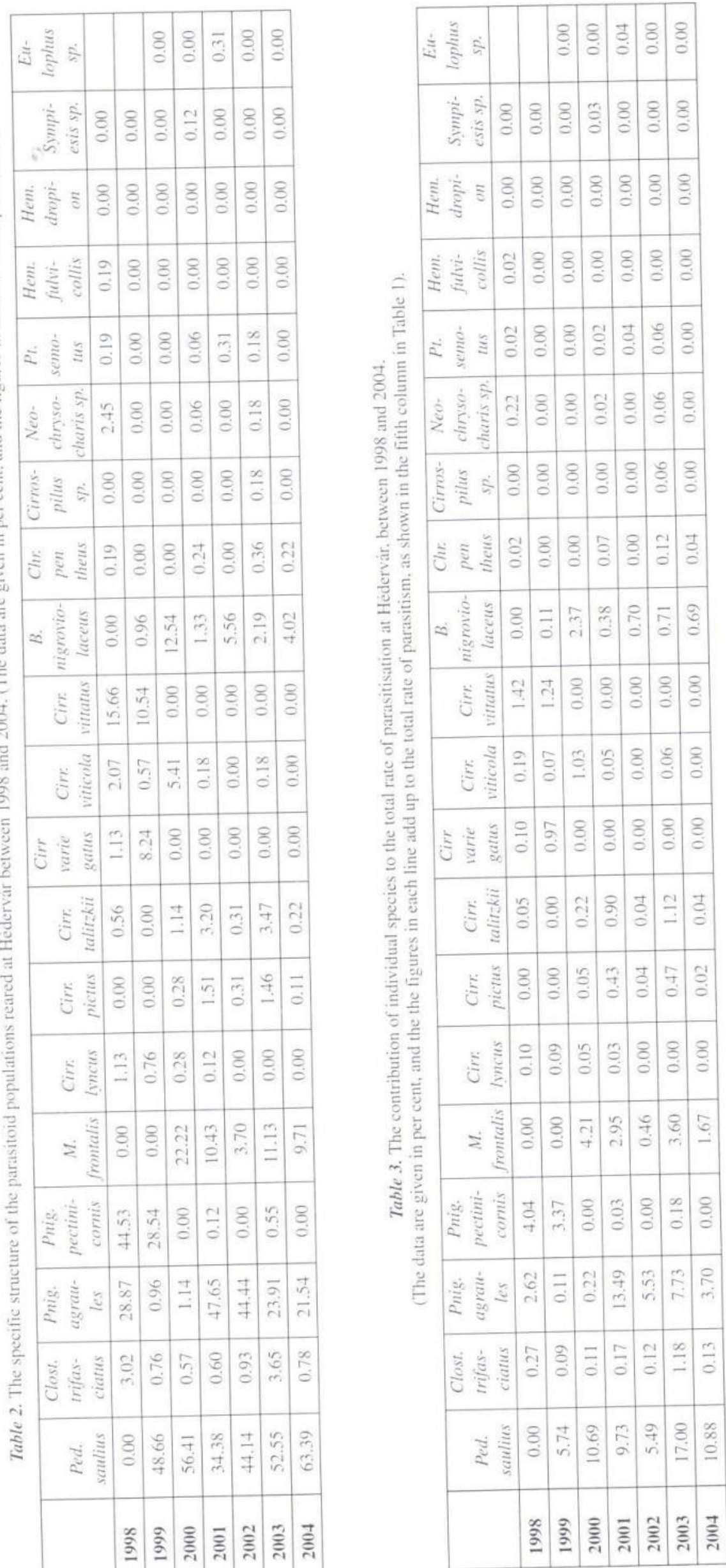
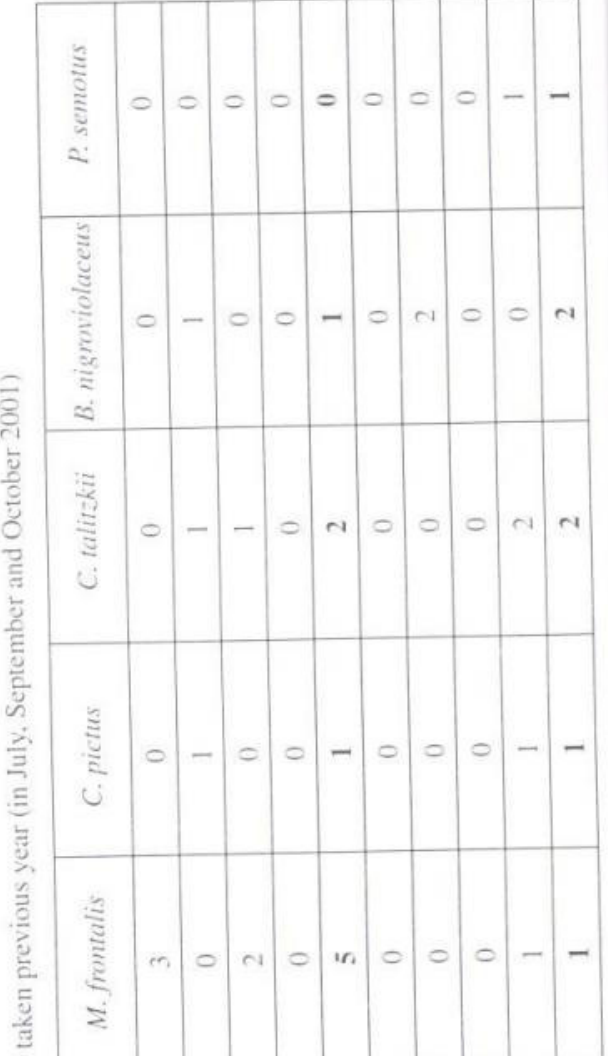

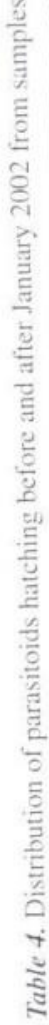

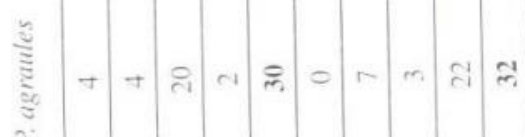

$\frac{\text { है }}{\text { है }}$

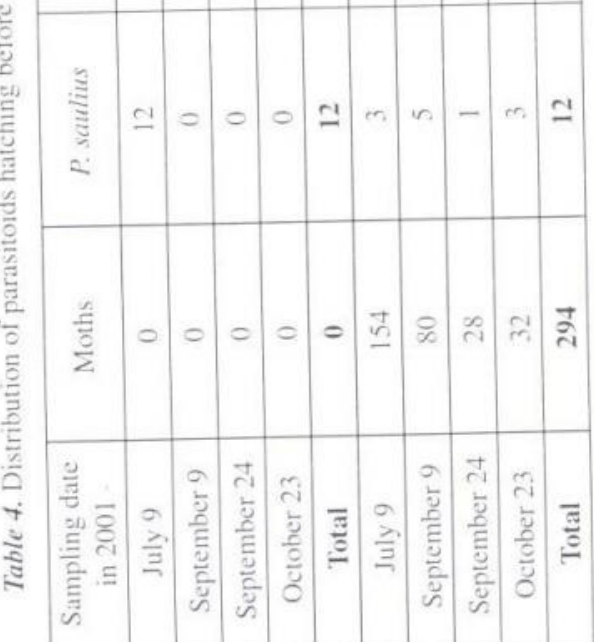

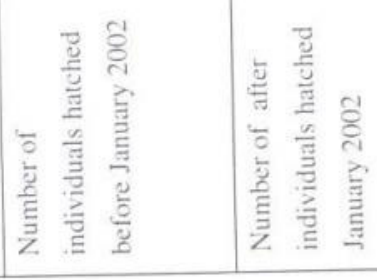


leafminer is a constant process with a higher speed than usually suggested. Nonetheless, the degree of adaptation cannot always be manifested in an adequate rate of parasitism as the visible effect of parasitoids is highly influenced by actual weather conditions. We assume that, even in years when parasitoids are less abundant, adaptation goes on with a considerable pace.

Our results contradict the opinion that the adaptation of the native parasitoids to the invasive host was very slow (Grabenweger 2004a,b). According to the author cited parasitism levels remain low even at places with more than 10 years of continuous $C$. ohridella infestation.

One possible reason for the contradictory results can be that studies up to now are usually based on 3-year experiments which is a too short time to discover tendencies in the changes of parasitism. For instance, in the period of our investigations, years 2000-2001-2002 or 2001-2002-2003 or 2002-2003-2004 on their own would not allow to realize any tendency. Poor realization of tendencies is especially probable if the investigation period contains a year with irregular or adverse weather conditions which has occurred quite often recently all over Europe. We think longer investigations are more appropriate to explore direction of changes.

As an additional explanation, authors might have left out of consideration that different leaf types or leaves in different levels of the tree canopy can show different rates of parasitism. Collecting samples from one part of the tree in one year and from another part of the tree the other year can have a great effect on the results.

Searching for possible causes there is one thing more that should be taken into consideration. Most examinations published so far were made on urban locations where the lack of vegetation under the trees makes it possible to collect fallen leaves thoroughly in the autumn. Removing and composting leaf litter is an efficient and inexpensive means of controlling $C$. ohridella population and is generally recommended (e. g. Reiderné et al. 1996, Šefrová 2001, Kükedi 2001, Grabenweger 2001, Gilbert et al. 2003, Kehrli \& Bacher 2004). On the other hand, composting fallen leaves accompanies exterminating parasitoids as well which leads to slowing down adaptation. In many urban areas, prevention methods may contribute to the fact that parasitism rates often remain low even after several years of continuous infestation.

\section{The parasitoid community}

Altogether 20 species of parasitoids could be reared during the 7-year investigation (Tables 2-3). Data in Table 1 show that in neither year occurred all the 20 of them but the parasitoid community always consisted of at least 8 but not more than 14 species. There was a recession even in the number of species in 2002 and 2004 that possibly can be ascribed to adverse weather conditions.

There were only 5 species that occurred in all 7 years. Pnigalio agraules and Minotetrastichus frontalis were usually quite abundant compared to other species (Table 2).
Baryscapus nigroviolaceus, especially in the last years, was much more scarce while Closterocerus trifasciatus or Cirrospilus pictus hatched only in very low numbers. Irrespective of the individual numbers, all 5 species were stable members of the parasitoid community.

Pediobius saulius is a remarkable species that could not be reared in 1998 but a year later almost half of all parasitoid individuals belonged to this species. From this year on it was a dominant or subdominant parasitoid of $C$. ohridella.

Cirrospilus talitzkii appeared in 2000 for the first time but since then it could be reared every year. Pnigalio pectinicornis was not among the most abundant chalcidoids but it occurred at least in 2 years and maybe also in 19981999. The uncertainty is due to the minor differences between $P$. pectinicornis and $P$. agraules that was not examined during the first two years.

Additional 4 species hatched only in 2 years and there were 5 parasitoids that occurred only in a single year and then disappeared. We found three of them only in 1998 (Cirrospilus. variegatus, Hemiptarsenus dropion, $H$. fulvicollis).

\section{Stability of parasitoid populations}

According to a most accepted and well-founded opinion, development of $C$. ohridella and its parasitoids are poorly synchronized (Grabenweger 2004a,b). Parasitoids overwintering in the leaf mines of the horse-chestnut trees wander away and seek suitable leafminer hosts on other plants. Later in the summer, the larvae of the first moth generation are attacked by parasitoid individuals that come from other host species from nearby plants. The assumption is supported by the observation that the constitution of the parasitoid community in the first and third generations of the moth is quite different. According to this opinion, rates of parasitism in one year should not correlate with the same a year earlier. Parasitism of the first generation is low irrespective of the parasitism of the third generation in the previous year (Grabenweger 2001, 2004a).

We examined whether the latter statement holds on the location at Hédervár between 2001-2004. Figure 1 shows parasitism rates of $C$. ohridella in the period of 2001-2004. Changing of the years 2001 and 2002 is very sharp indeed: parasitism of $55.8 \%$ at the end if 2001 abruptly decreases to $6.5 \%$ at the start of 2002 . The populations of the parasitoids manage to recover recession only by the end of the year. However, there is hardly a decrease between the years 2002-2003 or 2003-2004. According to the histogram on Figure 1 the rates of parasitism were strongly fluctuating in the period 2002-2004 but a breaking between the years cannot be realized in spite of the hibernation periods of 7 months between the seasons. The results imply that parasitism of the horse chestnut leafminer strongly depends on the parasitism in the previous year. Of course, rates can be decreased by adverse weather conditions or other factors as seen in early 2002 or late 2004.

Look at Table 5 to find an explanation why recessions in parasitism occurred in the years mentioned. The unusually 


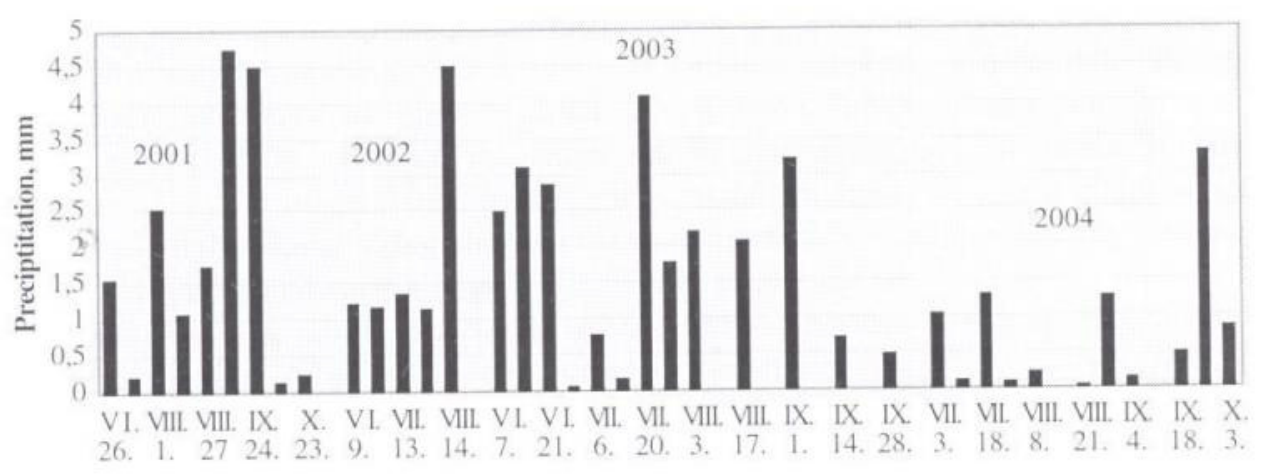

Figure 2. Average daily amounts of precipitation in periods prior to sampling dates in Mosonmagyarovair between 2001 and 2004

Table 5. Mean values of weather factors between July 18 and September 11 (Mosonmagyarovar)

\begin{tabular}{|c|c|c|c|}
\hline & \multicolumn{2}{|c|}{ Mean daily amount (value) of } & \multirow{2}{*}{ Mean temperature ( ${ }^{\circ} \mathrm{C}$ ) } \\
\cline { 1 - 2 } Year & Precipitation (mm) & Sunny hours & \\
\hline 2001 & 2.50 & 7.95 & 20.25 \\
\hline 2002 & 2.13 & 7.46 & 20.95 \\
\hline 2003 & 1.62 & 9.37 & 21.57 \\
\hline 2004 & 0.35 & 8.75 & 19.95 \\
\hline
\end{tabular}

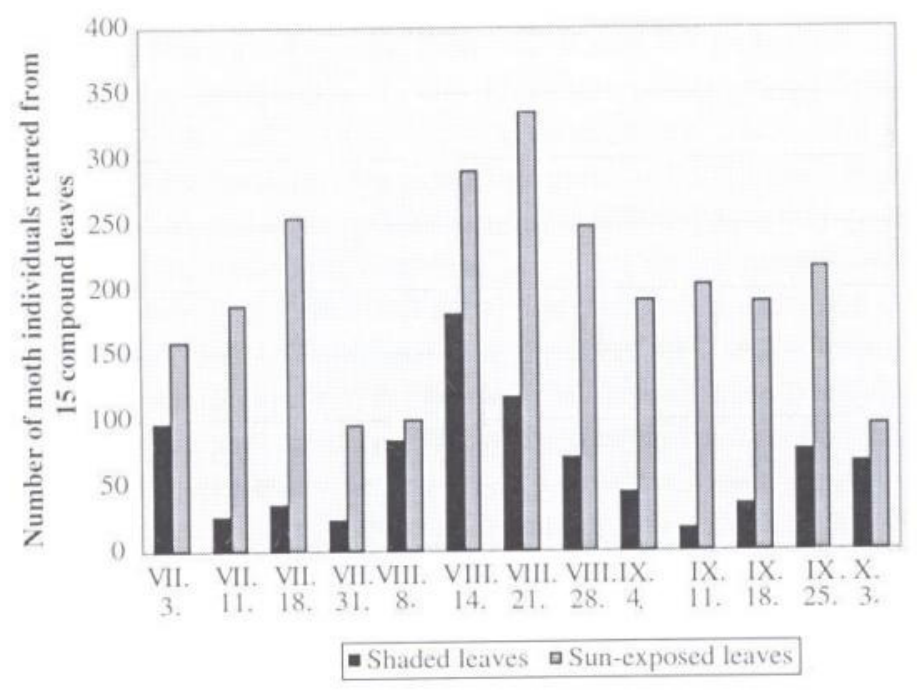

Figure 3. Number of Cameraria ohridella adults hatching from leaf samples taken at sun-exposed and shaded parts of the canopy (Hédervár, 2004)

low amounts of precipitation from July 2004 right to the end of the sampling period (Figure 2) coincide with low rates of parasitism between July 18 and September 11, 2004 (Figure I). The average daily amounts of precipitation in this time of the years was decreasing (data on the courtesy of the Meteorological Station of the University of West Hungary, Mosonmagyaróvảr), reaching a very low value of $0.35 \mathrm{~mm}$ in 2004 (this is roughly one-fifth of the value in 2003, see Figure 2, Table 5). In the same time, the number of sunny hours was the second highest, the average daily mean temperature - although the lowest among the 4 years - only lags behind with $1.6^{\circ} \mathrm{C}$ from the value of 2003 .

Probably due to higher than optimal temperatures and lack of water in mines, direct sunlight affects moth development adversely (Birner \& Bohlander 2004). Combined with very low amount of precipitation, this could have a negative effect on the number of the moths per one leaf from the end of August.

According to these considerations, we suppose that larvae of parasitoids are even more sensitive to high temperatures or lack of water in the mines than leafminer larvae. However, more moth larvac occur per leaf at sun-exposed parts of the canopy than is the shade (Figure 3), the rate of parasitism of the larvae is higher at shaded than in the sunexposed parts of the canopy. This means greater proportion of moth population can avoid parasitism in sunny part of the canopy than in the shade. That is why rate of parasitism was low at the end of the season 2004. Our assumption is supported by the fact that the difference between shaded and sun-exposed leaves regarding rate of parasitism was fairly high at this time of the year (Figure 4), with much higher values for the shaded ones. The difference can be attributed mainly to $P$. agraules (Figure 5) and M. frontalis.

Recession in the parasitism early in the 2002 season (Figure l) can be explained on the basis of the coldest winter temperatures (Horvaith \& Benedek, in preparation).

Of course, the adaptation process can go on even if the parasitoids inmigrate and emigrate every year but the high pace we found implies that chalcidoid species form more or less stable and permanent populations around the horsechestnut trees. Yearly migrations would decrease the probability of partly adapted parasitoid individuals coming back and would also lessen pace of global adaptation. Increasing adaptation to $C$. ohridella probably reduces adaptation level to other host species so the chance for a yearly host change decreases in any way.

Other leafminer species such as Leucoptera malifoliella Costa probably have permanent parasitoid populations. $L$. malifoliella has been known since 1982 in Hungary. The adult moths overwinter and swarm in April and May, has two or three generations per year (Molnár J.-né 2004) and most of its parasitoids (Balázs \& Mészáros 1998) are common with that of $C$. ohridella. Despite its similar phenology, the same parasitoids can effectively control the population of the moth (Balazs \& Mészáros 1998). The most important parasitoid of L. malifoliella is Chrysocharis pentheus which flies when $\mathrm{L}_{2}$ instars of the moth are abundant in the leaves (Balázs \& Mészáros 1998). On the other hand, C. pentheus plays a much less important role in the parasitoid community of $C$. ohridella though $\mathrm{L}_{2}$ instars of the horse-chestnut leafminer must be present at the same or similar time. It is probable that there are some other causes beyond insufficient syncronisation between the developments of $C$. ohridella and Chrysocharis pentheus. This assumption is probably true for other parasitoids of $C$. ohridella as well since in some cases we cannot explain with different flight times why parasitoids 
Rate of parasitism in shaded and sun-exposed leaves (Hédervár, 2004)

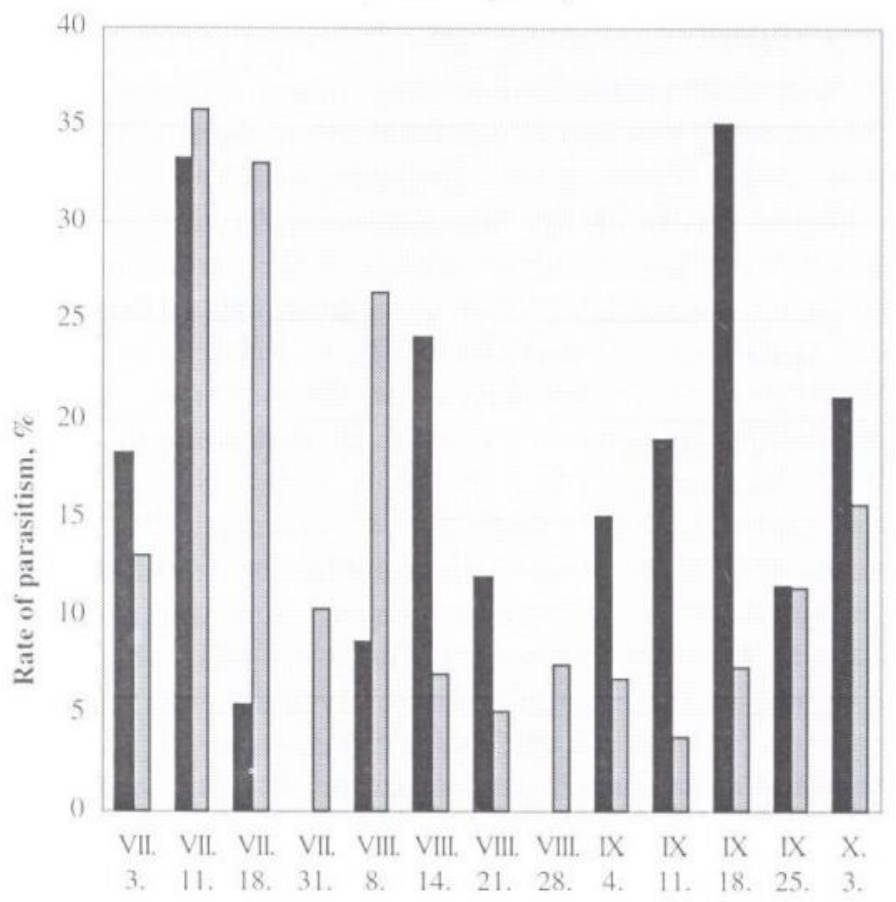

- Shaded leaves a Sun-exposed leaves

Figure 4. Rate of parasitism in shaded and sun-exposed leaves (Hédervair. 2004)

Conntribution of Pnigalio agraules to the parasitism of C. ohridella in shaded and sun-exposed leaves (Hédervair, 2004)

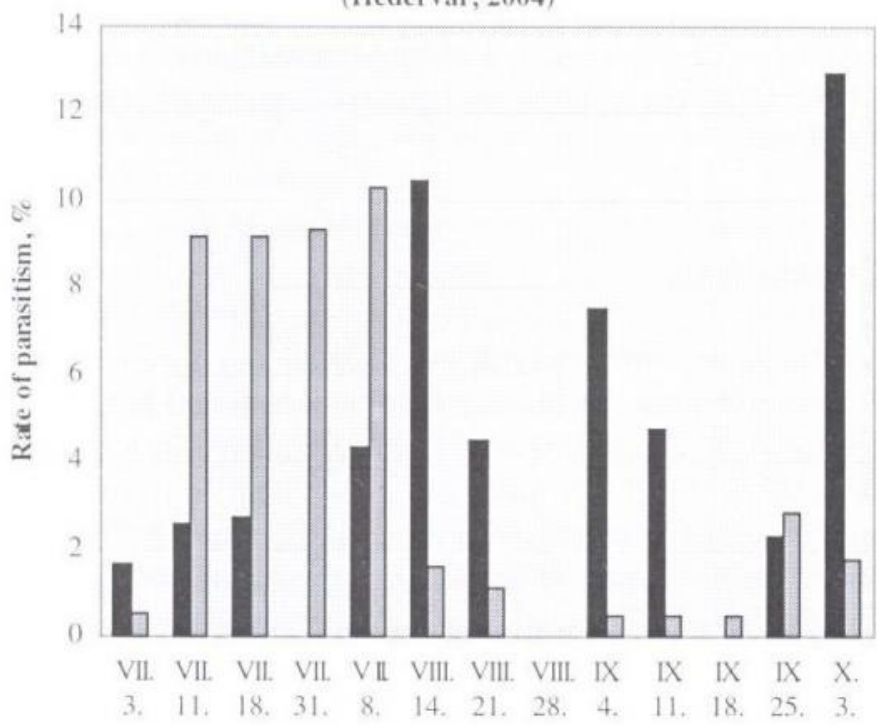

- Shaded leaves a Sun-exposed leaves

Figure 5. Contribution of Pnigalio agraules to the parasitism of C. ohridella in shaded and sun-exposed leaves (Hédervair. 2004)

prefer different larval stages of the moth (Horvath \& Benedek, in preparation).

According to several investigations, the massive flight periods of the parasitoids precede the appearance of the larval stages of $C$. ohridella that are most suitable for parasitisation (Horvath \& Benedek, in preparation, Grabenweger 2004a) and the majority of the parasitoids hatch before the moths' swarming time (Grabenweger 2001, Horvath \& Benedek 2001). With reference to these studies we must take into account that all leaf samples examined were kept in shade or in unheated rooms. However, the developmental threshold for most parasitoids is probably lower than for the horse-chestnut leafminer and their earlier swarming can be assigned to this fact. It is possible, that the fallen leaves under the trees are warmed up by direct sunlight in the spring and the temperatures in the mines rise considerably higher than they did under the circumstances of the investigations cited. As a result, the development of the moth pupae in the mines is accelerated to a greater extent than that of the parasitoid larvae or pupae with probably lower developmental thresholds. Consequently, the flight of the parasitoids and the appearance of the larval instars suitable to parasitization may come nearer to each other than recent examinations suggest, allowing more synchronized developement and permanent settling of parasitoid populations. Balázs and Thuróczy (1999) report that in 1998, due to the cold spring (temperatures probably below the threshold of both the host and the parasitoids) and then a sudden rise in temperature (temperatures probably well over the highest threshold) the swarming times of the moth and its parasitoids took place at the same time. It does not mean the elimination of the synchronization problem but suggests that the parasitoids have more room to adapt to the host than widely thought based on indoor investigations.

In order to prevent possible undesired destruction of parasitoids a promising alternative control method has been proposed by Kehrli et al. (2005) as using mass-emergence devices with an appropriate mesh size. In this method, leaf litter is stored in large containers from that insects can emerge through a filter allowing parasitoids to leave but retaining the moths for they being larger and so allowing reproduction of more or less adapted chalcidoids. (A similar method has been used for a long time to control Cydia pomonella, Hyphantria cunea or Phyllonorycter sp.: Balazs \& Mészáros 1989)

\section{Infestation level of the horse-cestnut leaves}

During the 7 years of our investigations, there were considerable differences in the number of moths that hatched from a given amount of horse-chestnut leaves (Table I). When the number of the moths per leaf increased from one year to the other, the rate of parasitism decreased and the opposite almost at all instances. For some reason, parasitism was higher in years that were unfavourable for the horsechestnut leafminer. However, the changes in the infestation levels were not the result of parasitoid action, as rates of parasitism were too low to be the main factor. A similar phenomenon was described by Nejmanová et al. (2004) who report that horse-chestnut leafminer populations stressed by unfavourable conditions such as presence of insecticides in subletal concentrations or developement in suboptimal host plants suffer a higher rate of parasitism. 
The infestation level was generally decreasing but in 2002 and 2004 there were two peaks, right in the years when parasitism had depressions (Figure 1). This makes questionable if changes in parasitism were really due to changes in weather conditions as we suggested previously. We suppose that there are additional factors in the background that should be revealed by further investigations.

\section{Contribution of individual chalcidoid species to the total rate parasitism}

As data in Table 3 show, 2002 and 2004 were unfavourable years for all parasitoids so low rates of parasitism in these years were not the effect of population changes in one or two dominant species but were caused collectively by almost all chalcidoids. $B$. nigroviolaceus and $P$. semotus are exceptions: their contribution to the parasitism grew from 2001 to 2002 that is indicated by higher proportions of their individuals as well.

The increase in the overall rate of parasitism in 19982001 (Table 1 ) is not always registered in the figures in Table 3 . The growth in the first 3 years was mainly due to the gradual spreading of Pediobius saulius, while the peak value in 2001 can also be attributed to the Pnigalio species, especially to the much more abundant $P$. agraules.

Data in Table 2 imply that Pediobius saulius is gaining ground in the parasitoid community apart from the slight recession in the first years of the new millennium. On the contrary, Pnigalio agraules shows a sudden growth in 2001 but its relative abundance is decreasing in the last 4 years. Minotetrastichus frontalis is a remarkable species that was dominant in the parasitoid community in 1998 but its importance has greatly decreased since then. There was a very similar tendency in the relative abundance of Baryscapus nigroviolaceus.

\section{Distribution of parasitoids hatching before and after next January from autumn samples}

From leaf samples collected in 2001 none of the individuals of the horse-chestnut leafminer hatched before January 2002 (Table 4). This result was expected for the samples from September-October 2001 since leaf mines in this time contain individuals of the third generation that produced pupae with cocoons. This type of pupae overwinter and hatch only next spring (Freise \& Heitland 2004). Interestingly, from samples collected in July 2001 did not hatch adult leafminers either before January 2002. According to the study cited, the proportion of the pupae without cocoons (the type that usually does not overwinter) was highest at early July (at least in the study of Freise \& Heitland 2004, at Freising and Langenbach in 1999). One possible reason for the difference is that there can be considerable differences in the speed of development between years and locations, depending on weather conditions, and a relatively short time is sufficient to change greatly the proportions of the two types of pupae. For instance, on the locations Freising and Langenbach in 1999. one and a half months were needed for turning reversed these proportions.

Part of the parasitoid individuals in the mines hatched in the sampling year (2001), and the rest of them in the next year (2002), generally in a proportion of ca. 1 to 1 . This statement can be clearly illustrated with Pnigalio agraules that was the most common species of the parasitoids. The emerging individuals of that were distributed between the two years close to equal (30 to 32). C. trifasciatus and $M$, frontalis were exceptions, since the majority of their population emerged in 2001, and much smaller proportion in 2002 (the ratio was 4 to 1 and 5 to 1 , resp.). P. semotus that was represented by one individual only hatched in 2002.

Looking at the samples taken at different data separately, the picture with Pnigalio agraules is more differentiated. Namely, from the samples collected at 24 September 2001 , 20 individuals emerged before January 2002 and 3 individuals later. On the other hand, from the samples collected a moth later, at 24 October 2001 , the proportion was roughly the reverse ( 2 to 22 ). These reciprocal values imply that $P$. agraules is still able to find suitable hosts at the end of September or even early October but hardly any more at the end of October or later. Of course, the suitable host is possibly not the $C$. olvidella but some other leafminer species since its development is not synchronized with that of C. ohridella (Grabenweger 2004a,b).

Nevertheless, it is plausible that rates of parasitism we determined in 1998-2000 would be somewhat higher if parasitoid individuals that hatched in the autumn would have been taken into account as well. By all means, the differences would be moderate due to the late sampling dates (October or February).

\section{Conclusions}

Based on our examinations carried out throughout 7 consecutive years we suggest that the infestation level of $C$. ohridella at a given newly invaded locality is generally decreasing and the rate of parasitism is increasing simultaneously, the rate of decrease and increase, however, is under the influence of the changing weather and so this tendency can be detected only during a period long enough. Accordingly, our results contradict the opinion of previous contributors that the adaptation of the native parasitoids to an invasive host is always very slow because in the case of horse chestnut leafminer this process seems to be fairly rapid when studying the parasitism for a period long enough ( 7 years in our case), that is for longer time than 2-3 years only like in previous studies. A possible adaptation of the parasitoids to this new host is showed on the gradually changing rate of parasitism.

In contradiction with earlier studies we assume that a partially stable and permanent parasitoid community is being developed around the horse-chestnut leafminer. Proportions of adult moths and parasitoids hatched in the same year of 
sampling or the next year were determined. The results imply that parasitism of the horse chestnut leafminer strongly depends on the parasitism in the previous year.

We suppose that larvae of parasitoids are even more sensitive to high temperatures or lack of water in the mines than leafminer larvae.

\section{Acknowledgements}

The authors wish to thank Csaba Thuróczy for his indispensable help in the identification of the parasitoids.

\section{References}

Balázs K. (1997): The Importance of Parasitoids in Apple Orchards. Biol. Agric. \& Hortic. 15: (1-4) 123-129.

Balázs K. \& Mészáros Z. (eds.)(1989): Biológiai védekezés természetes ellenségekkel. Mezőgazdasági Kiadó, Budapest. pp. 183.

Balázs K. \& Mészáros Z. (1998): Lepkék - Lepidoptera. In Jenser G. - Mészáros Z. - Sáringer Gy. (eds.) (1998): Szántóföldi és kertészeti növények kártevöi. Mezögazda Kiadó, Budapest. pp. 311-314.

Balázs K. \& Thuróczy Cs. (1999): A vadgesztenyelevél-aknázòmoly parazitáltsága a környezet diverzitásának függvényében. 45 . Növényvédelmi Tudományos Napok, Budapest (February 23-24. 1999) pp. 39.

Balázs K. \& Thuróczy Cs. (2000): Über den Parasitoidkomplex von Cameraria ohridella Deschka et Dimie 1986, (Lepidoptera, Lithocolletidae), Entomologica Basiliensia 22: 269-277.

Birner, A \& Bohlander, F. (2004): Mine development of horse chestnut leaf-miner (Cameraria ohridella) on leafs exposed to sunlight or shade. 1st International Cameraria Symposium, Prague (March 24-27, 2004) pp. 5.

Freise, J. \& Heitland, W. (2004): Bionomics of the horse-chestnut leafminer Cameraria ohridella Deschka \& Dimie 1986, a pest on Aesculus hippocastanum in Europe. Senckenbergiana biologica 84: (1/2) 1-20.

Gilbert, M., Svatos, A., Lehmann, M. \& Bacher, S. (2003): Spatial patterns and infestation processes in the horse chestnut leafminer Cameraria ohridella: a tale of two cities. Entomol. Exp. Appl. 107: 25-37.

Grabenweger, G. (2001): Auswirkungen der Fallaubentfernung auf Cameraria ohridella Deschka \& Dimia (Lepidoptera, Gracillariidae) und ihre Parasitoiden. Mitt. Dtsch. Ges, allg. angew. Ent. 13: 141-143.

Grabenweger, G. (2003): Parasitism of different larval stages of Cameraria ohridella. BioControl 48: 671-684.

Grabenweger, G. (2004a): Poor control of the horse chestnut leafminer, Cameraria ohridella (Lepidoptera: Gracillariidae), by native European parasitoids: a synchronisation problem. Eur. J. Entomol. 101: 189-192.
Grabenweger, G. (2004b): Why are native European parasitoids not able to control the horse chestnut leafminer? 1st International Cameraria Symposium, Prague (2004. március 24-27.) pp. 12.

Horváth B. \& Benedek P. (2001): Parasitoiden der RoßkastanienMiniermotte (Cameraria ohridella Deschka Dimič, 1986) in Nordwest-Ungarn. Acta Agronomica Óváriensis 43: (1) 35-48.

Kehrli, P. \& Bacher, S. (2004): How to safely compost Cameraria ohridella-infested horse chestnut leaf litter on private compost heaps. JEN (manuscript)

Kehrli, P., Lehmann, M. \& Bacher, S. (2005): Mass-emergence devices: a biocontrol technique for conservation and augmentation of parasitoids. BioControl 32: 191-199.

Kükedi E. (2001): A vadgesztenyelevél-aknázómoly (Cameraria ohridella Deschka et Dimiě Lep. Lithocolletidae). Növényvédelmi Tanácsok 10: 14-17.

Lupi, D. (2005): A 3 year field survey of the natural enemies of the horse-chestnut leaf miner Cameraria ohridella in Lombardy, Italy. BioControl 50: 113-126.

Molnár J.-né (2004): A kártevö állatok elleni védekezés. In Inántsy F. - Balázs K. (eds.) (2004); Integrált növénytermesztés: Alma. Agroinfrom kiadó, Budapest. pp. 213-214.

Nejmanová, J., Cvačka, J., Hrdỳ, I., Kuldová, J., Muck, A. jr. \& Svatoš, A. (2004): Residues of diflubenzuron on horse chestnut leaves and efficiency of insecticides against the horse chestnut leafminer (Cameraria ohridella) with notes on its parasitisation. Ist International Cameraria Symposium, Prague (March 24-27, 2004) pp. 36.

Reider Imréné, Szeöke K. \& Tóth B. (1996): A vadgesztenyelevél-aknảzómoly hazai elterjedése és a védekezés lehetöségei. Integrált termesztés a kertészetben 17: 95-97.

Reider Saly K., Thuróczy Cs., Urfi Fogarasi E. \& Ripka G. (1999): Survey of hymenopterous pupal parasitoids of horse chestnut leafminer [Cameraria ohridella Deschka et Dimič 1986 (Lepidoptera: Gracillariidae)] in Hungary in 1996-1998. Higher School of Agriculture, Scientific Works 44: (2)

Šefrová, H. (2001): Control possibility and additional information on the horse-chestnut leafminer Cameraria ohridella Deschka \& Dimiě (Lepidoptera, Gracillariidae). Acta univ. agric. et silvic. Mendel. Brun. 49: (5): 121-127.

Šefrova, H. \& Laštüvka, Z. (2001): Dispersal of the horse-chestnut leafminer, Cameraria ohridella Deschka \& Dimič 1986, in Europe: its course, ways and causes (Lepidoptera: Gracillariidae). Entomol. Zeitschrift 111, (7): 194-198.

Šefrová, H. (2003): Invasions of Lithocolletinae species in Europe - causes, kinds, limits and ecological impact (Lepidoptera, Gracillariidae). Ekológia (Bratislava) 22: (2): 132-142.

Szabóky Cs. \& Vas J. (1997): Újabb adatok a vadgesztenyelevélaknázómolyról (Cameraria ohridella Deschka \& Dimič 1986, Lep. Lithicolletidae). Növényvẻdelem 33: (1): 29-31.

Thuróczy Cs. \& Reider Imréné (1998): A vadgesztenyelevélsaknázómoly parazitáltságának és a hasznos élö szervezeteknek a vizsgálata a fövảrosi és a megyei NTÁ-k eredményei alapján. Növényvédelmi Tudományos Napok, Budapest (February 24-25, 1998) 